\title{
Increased plasma phenylacetic acid in patients with end-stage renal failure inhibits iNOS expression
}

\author{
J. Jankowski, ${ }^{1}$ M. van der Giet, ${ }^{1}$ V. Jankowski, ${ }^{1}$ S. Schmidt,${ }^{1}$ M. Hemeier, ${ }^{1}$ B. Mahn, ${ }^{1}$ \\ G. Giebing, ${ }^{1}$ M. Tölle, ${ }^{1}$ H. Luftmann, ${ }^{2}$ H. Schlüter, ${ }^{1}$ W. Zidek, ${ }^{1}$ and M. Tepel ${ }^{1}$ \\ ${ }^{1}$ Medizinische Klinik IV, Universität-Klinikum Benjamin Franklin, Freie Universität, Berlin, Germany \\ ${ }^{2}$ Lehrstuhl für Organische Chemie, Universität Münster, Münster, Germany
}

\begin{abstract}
NO prevents atherogenesis and inflammation in vessel walls by inhibition of cell proliferation and cytokine-induced endothelial expression of adhesion molecules and proinflammatory cytokines. Reduced NO production due to inhibition of either eNOS or iNOS may therefore reinforce atherosclerosis. Patients with end-stage renal failure show markedly increased mortality due to atherosclerosis. In the present study we tested the hypothesis that uremic toxins are responsible for reduced iNOS expression. LPS-induced iNOS expression in mononuclear leukocytes was studied using real-time PCR. The iNOS expression was blocked by addition of plasma from patients with end-stage renal failure, whereas plasma from healthy controls had no effect. Hemofiltrate obtained from patients with endstage renal failure was fractionated by chromatographic methods. The chromatographic procedures revealed a homogenous fraction that inhibits iNOS expression. Using gas chromatography/mass spectrometry, this inhibitor was identified as phenylacetic acid. Authentic phenylacetic acid inhibited iNOS expression in a dose-dependent manner. In healthy control subjects, plasma concentrations were below the detection level, whereas patients with end-stage renal failure had a phenylacetic acid concentration of $3.49 \pm 0.33 \mathrm{mmol} / 1(n=41)$. It is concluded that accumulation of phenylacetic acid in patients with end-stage renal failure inhibits iNOS expression. That mechanism may contribute to increased atherosclerosis and cardiovascular morbidity in patients with end-stage renal failure.
\end{abstract}

J. Clin. Invest. 112:256-264 (2003). doi:10.1172/JCI200315524.

\section{Introduction}

$\mathrm{NO}$ is an important signaling molecule that mediates a variety of essential physiological processes including neurotransmission, vasodilation, and host cell defense (1). $\mathrm{NO}$ is synthesized from L-arginine by nitric oxide synthase (NOS). Three distinct isoenzymes of NOS are known. Two calcium/calmodulin-dependent constitutive NOS isoenzymes dominantly expressed in the brain and endothelium and a calcium-independent, cytokine iNOS have been identified so far. NO inhibits cell proliferation, cytokine-induced endothelial expression of adhesion molecules, and proinflammatory cytokines (2-4).

$\mathrm{NO}$ generally is protective against atherogenic stimuli in the vessel wall (5). Vascular NO can be produced principally by two cell types, namely endothelial cells and VSMCs $(6,7)$. In normal vessels endothelial NO production is sufficient to meet the requirements of vascular

Received for publication March 25, 2002, and accepted in revised form May 13, 2003.

Address correspondence to: J. Jankowski, Freie Universität Berlin, Universitätsklinikum Benjamin Franklin, Medizinische Klinik IV, Hindenburgdamm 30, 12200 Berlin, Germany. Phone: 49-30-8445-1741; Fax: 49-30-8445-1762; E-mail: Joachim.Jankowski@medizin.fu-berlin.de.

Conflict of interest: The authors have declared that no conflict of interest exists.

Nonstandard abbreviations used: nitric oxide synthase (NOS); chronic renal failure (CRF); nuclear magnetic resonance (NMR); phenylacetic acid (PAA); triethylammonium acetate (TEAA); trifluoroacetic acid (TFA); proton-NMR $\left({ }^{1} \mathrm{H}-\mathrm{NMR}\right)$; parts per million (ppm); 3-trimethylsilyl-[2,2,3,3,-2 $\left.\mathrm{H}_{4}\right]$-propionate (TSP). regulation. NO production by VSMCs is not activated (6). On the other hand, under the conditions of endothelial dysfunction, NO production by endothelial cells may not be sufficient to defend the vascular wall against oxidative damage. In this setting, VSMCs increase their NO synthesis as a compensatory mechanism $(8,9)$. Therefore, VSMC-derived NO can be assumed to play a critical role under pathological conditions characterized by endothelial dysfunction. VSMC-derived NO is solely produced by iNOS, which is also expressed in leukocytes, but not in endothelial cells. Excess NO production by iNOS is implicated in the pathogenesis of vascular remodeling and atherosclerosis (10), because it causes inhibition of cell proliferation and apoptosis of VSMCs $(3,11)$, mesangial cell proliferation, and ECM synthesis (12). Obviously, studies on iNOS expression in human VSMCs are limited by the difficulty in obtaining samples of vascular tissue. Since iNOS is expressed in both VSMCs and leukocytes, the latter may be a suitable model to study iNOS expression in human pathology. Therefore, in the present study mononuclear leukocytes are used as a model for examining the effects of uremic toxins on iNOS expression.

Atherosclerosis is a major cause of morbidity and mortality in chronic renal failure (CRF) $(13,14)$. Increased cardiovascular mortality in patients with CRF is due in part to the prevalence of established risk factors for atherosclerosis such as hypertension or an increased serum level of LDLs or lipoprotein $(\mathrm{a})(14,15)$. Abnormalities of the NO synthetic pathway have a key role in the pathogenesis of atherosclerosis in patients with $\operatorname{CRF}(14,16)$. In 
CRF patients NO bioavailability is reduced (17). A marked reduction of $\mathrm{NO}$ in the face of continuous local generation of vasoconstrictor and mitogenic substances contributes to intraglomerular hypertension (18), cell proliferation, and atherosclerosis. In glomeruli, soon after surgical ablation, renal mass inflammatory mediators such as PDGF (19) and TGF- $\beta$ (20) are formed in excessive amounts. PDGF and TGF- $\beta$ are both potent inhibitors of $\mathrm{NO}$ synthesis and dose-dependently block IL-1 $\beta$-induced iNOS mRNA in rat mesangial cells (21). Reduced NO production may be ameliorated by pharmacological tools such as L-arginine (22).

To identify factors decreasing the iNOS expression in $\mathrm{CRF}$ we investigated the effects of plasma and hemofiltrate obtained from patients with end-stage renal failure on iNOS expression. Hemofiltrate was fractionated by chromatographic methods, and the effect of the resulting fractions on iNOS expression was examined. The chromatographic procedures revealed a homogenous fraction that reduces iNOS expression in mononuclear leukocytes. Using gas chromatography/mass spectrometry and comparison of the data of the mass spectrometry with pertinent databases, the inhibitor of LPSinduced iNOS expression was identified as phenylacetic acid (PAA). Using nuclear magnetic resonance (NMR), increased plasma concentrations of PAA could be measured in patients with end-stage renal failure.

\section{Methods}

Patients. The study was approved by the local ethical committee, and informed consent was obtained from the patients. Forty-one patients with end-stage renal failure who had been undergoing maintenance hemodialysis for $40 \pm 5$ months (mean \pm SEM) were enrolled in this study. Moreover, 39 subjects with normal renal function were used as a control group. The cause of end-stage renal failure was diabetic nephropathy in 16 cases, nephrosclerosis in nine cases, chronic glomerulonephritis in four cases, and unknown in 12 cases. Patients were stable and free from intercurrent illness. As confirmed by the clinical examination, patients were in a good state of health. All of the patients were routinely dialyzed for $4-5$ hours three times weekly using biocompatible polysulfone hemodialysis membranes (F60; Fresenius Medical Care, Bad Homburg, Germany) with no dialyzer reuse. Water and dialysate used in hemodialysis were in accordance with the recommendations of the American Association of Medical Instrumentation. Bacterial growth was less than $50 \mathrm{CFU} / \mathrm{ml}$ in water and less than $200 \mathrm{CFU} / \mathrm{ml}$ in dialysate as described (23). We obtained $500 \mathrm{ml}$ hemofiltrate from five patients with end-stage renal failure undergoing regular treatment with hemofiltration.

Dialysis adequacy was estimated using $K t / V$ values (the amount of plasma cleared of urea divided by the urea distribution volume), which were determined using the formula $K t / V=-\ln (R-0.03)+(4-3.5 \times R) \times U F / W$, where $R=$ after/before plasma urea nitrogen ratio; $U F=$ ultrafiltrate volume (in liters) removed; and $W=$ postdialysis weight (in kilograms) $(24,25) . K t / V$ values were $1.2 \pm 0.1$ (mean \pm SEM). The clinical and biochemical characteristics of patients and control subjects are given in Table 1. From a subset of patients and controls (Table 1) plasmas were used for measurements of iNOS mRNA expression by real-time PCR.

Plasma from patients with end-stage CRF was obtained before the regular hemodialysis session. Using an EDTA VACUTAINER $\left(1.8 \mathrm{mg} / \mathrm{ml} \mathrm{K}_{2}\right.$-EDTA), blood was taken from the arterial site of the hemodialysis fistula immediately before starting dialysis session and was immediately centrifuged at $4,000 \mathrm{~g}$ and $20^{\circ} \mathrm{C}$ for 5 minutes. Thereafter, plasma was stored at $-20^{\circ} \mathrm{C}$.

To test whether significant amounts of PAA are protein bound in human blood plasma, a portion of plasma was deproteinized with $0.6 \mathrm{~mol} / \mathrm{l}$ perchloric acid. PAA concentration in the untreated and deproteinized portions of the sample were then compared as described below.

Chromatography of the hemofiltrate. The sequence of chromatographic separation steps described below was chosen for the following reasons. In the first step, displacement chromatography discards the bulk of interfering substances without overloading the column. For further steps, different reversed-phase procedures were chosen, dealing with considerably less material than the first, rough separation steps. To obtain optimum effects of a sequence of reversed-phase chromatographies, different ion-pair reagents were applied.

Hemofiltrate $(500 \mathrm{ml})$ was concentrated to dryness in a vacuum concentrator (freeze dryer; Snijders Scientific B.V., Tilburg, The Netherlands). The dried hemofiltrate was dissolved in $5 \mathrm{ml}$ of $40 \mathrm{mmol} / \mathrm{l}$ triethylammonium acetate (TEAA) in water (eluent A), and chromatography was performed (flow: $1.0 \mathrm{ml} / \mathrm{min}$ ) on a C18 reversed-phase column (LiChroprep, type B; Merck, Darmstadt, Germany) in the displacement mode (displacer: $160 \mathrm{mmol} / \mathrm{l} n$-butanol in eluent A). After each chromatographic step, the influence of the fractions on the iNOS expression was assayed.

Next, the fractions decreasing the iNOS expression were fractionated (flow: $0.5 \mathrm{ml} / \mathrm{min}$ ) on a $\mathrm{C} 18$ reversedphase HPLC column (LiChrosorb RP C18, 250 × $4.6 \mathrm{~mm}$; Merck) with $0.1 \%$ trifluoroacetic acid (TFA) in $\mathrm{H}_{2} \mathrm{O}$ as eluent $\mathrm{A}$ and $0.1 \%$ TFA in $\mathrm{CH}_{3} \mathrm{CN}$ as eluent $\mathrm{B}$ under the following gradient condition: $0-5$ minutes, $0-20 \%$ eluent $B$; 5 to 10 minutes, $20 \%$ eluent B; $10-30$ minutes, $20-40 \%$ eluent B; $30-40$ minutes, $40-60 \%$ eluent B; $40-45$ minutes, $60-100 \%$ eluent B; $45-50$ minutes, $100 \%$ eluent B.

Subsequently, the fractions decreasing the iNOS expression were chromatographed (flow: $0.5 \mathrm{ml} / \mathrm{min}$ ) on an additional reversed-phase column (Supersphere RP C18 endcapped, $250 \times 4.6 \mathrm{~mm}$; Merck) with the following gradient: $0-10$ minutes, $100 \%$ eluent $\mathrm{A}(20 \mathrm{mmol} / \mathrm{l}$ TEAA in water); $10-20$ minutes, $0-20 \%$ eluent $B$ (20 mmol/l TEAA in $\mathrm{CH}_{3} \mathrm{CN}$ ); $20-40$ minutes, $20-40 \%$ eluent $B ; 40-50$ minutes, $40-60 \%$ eluent $B$; $50-55$ minutes, $60-100 \%$ eluent B; $55-60$ minutes, $100 \%$ eluent B).

The final purification step was chromatography (flow: $0.5 \mathrm{ml} / \mathrm{min}$ ) on a reversed-phase HPLC column 
Table 1

Clinical and biochemical characteristics of patients with end-stage renal failure and healthy control subjects

\begin{tabular}{|c|c|c|c|c|}
\hline & \multicolumn{2}{|c|}{ Plasma samples for PAA quantification } & \multicolumn{2}{|c|}{ Plasma samples for real-time PCR } \\
\hline & $\begin{array}{l}\text { Patients with } \\
\text { end-stage renal failure }\end{array}$ & $\begin{array}{l}\text { Healthy } \\
\text { control subjects }\end{array}$ & $\begin{array}{l}\text { Patients with } \\
\text { end-stage renal failure }\end{array}$ & $\begin{array}{c}\text { Healthy } \\
\text { control subjects }\end{array}$ \\
\hline & $(n=41)$ & $(n=39)$ & $(n=6)$ & $(n=6)$ \\
\hline Age (years) & $45 \pm 2$ & $61 \pm 3$ & $62 \pm 8$ & $60 \pm 9$ \\
\hline Sex (male/female) & $25 / 16$ & $17 / 22$ & $4 / 2$ & $3 / 3$ \\
\hline Body weight (kg) & $74 \pm 2$ & $66 \pm 3$ & $73 \pm 11$ & $74 \pm 12$ \\
\hline Duration of dialysis (months) & $40 \pm 5$ & 0 & $36 \pm 30$ & 0 \\
\hline Systolic blood pressure (mmHg) & $149 \pm 4$ & $125 \pm 2$ & $138 \pm 12$ & $123 \pm 9$ \\
\hline Diastolic blood pressure $(\mathrm{mmHg})$ & $81 \pm 2$ & $70 \pm 2$ & $79 \pm 2$ & $78 \pm 5$ \\
\hline Hemoglobin (g/dl) & $11.3 \pm 0.3$ & $12.9 \pm 0.3$ & $11.2 \pm 0.8$ & $14.1 \pm 0.9$ \\
\hline Serum creatinine $(\mathrm{mg} / \mathrm{dl})$ & $7.2 \pm 0.4$ & $1.0 \pm 0.1$ & $9.4 \pm 2.5$ & $0.8 \pm 0.1$ \\
\hline Blood urea nitrogen $(\mathrm{mg} / \mathrm{dl})$ & $27 \pm 2$ & $17 \pm 1$ & $24 \pm 3$ & $16 \pm 1$ \\
\hline Total protein $(\mathrm{g} / \mathrm{l})$ & $73 \pm 2$ & $71 \pm 1$ & $72 \pm 3$ & $72 \pm 2$ \\
\hline
\end{tabular}

The corresponding plasma was used for real-time PCR. Data are mean \pm SEM.

(Supersphere RP C18 endcapped, $250 \times 4.6 \mathrm{~mm}$; Merck). The column was run in the gradient mode with $0.1 \%$ TFA in $40 \% \mathrm{CH}_{3} \mathrm{CN} / \mathrm{H}_{2} \mathrm{O}$ (eluent $\mathrm{A}$ ) and $0.1 \%$ TFA in $99.9 \% \mathrm{CH}_{3} \mathrm{CN}$ (eluent $\mathrm{B}$ ) (gradient: $0-10$ minutes, $0-20 \%$ eluent $B ; 10-20$ minutes, $20-30 \%$ eluent $B ; 20-40$ minutes, $30-100 \%$ eluent B; $40-45$ minutes $100 \%$ eluent $B$ ).

Mass analysis. The purified fraction was examined with gas chromatography/mass spectrometry. Therefore, the speed-vacuum-dried sample was dissolved in $\mathrm{N}$-methyl- $\mathrm{N}$-trimethylsilylfluoroacetic acid amide and incubated for 1 hour at $70^{\circ} \mathrm{C}$. The fractions were separated by gas chromatography (0-35 minutes, $80-280^{\circ} \mathrm{C}$; column: $150 \mathrm{RCN}$; carrier gas: helium; flow: $2 \mathrm{ml} / \mathrm{min}$ ) and identified by electron ionisation-mass spectrometry (MAT 8200; Thermo Finnigan, San Jose, California, USA). The mass data were analysed by using the NIST nass spectral database (National Institute of Standards and Technology, Gaithersburg, Maryland, USA).

Preparation and stimulation of mononuclear leukocytes. Mononuclear leukocytes were obtained from healthy subjects according to established techniques (26). Briefly, $20 \mathrm{ml}$ heparinized blood was drawn by venipuncture from the antecubital vein and centrifuged at $240 \mathrm{~g}$ for 15 minutes. After removing the supernatant, mononuclear leukocytes were isolated by layering $5 \mathrm{ml}$ diluted blood (1:1 vol with isotonic $\mathrm{NaCl})$ on $3 \mathrm{ml}$ Histopaque (5\%/6\% wt/vol Ficoll, density $1.077 \mathrm{~g} / \mathrm{ml}$; Sigma-Aldrich Chemie GmbH, Deisenhofen, Germany) and centrifugation at $240 \mathrm{~g}$ for 20 minutes. The mononuclear leukocyte interphase was carefully aspirated, washed three times in isotonic $\mathrm{NaCl}$ by centrifugation at $400 \mathrm{~g}$ for 5 minutes, and resuspended in HBSS containing (in millimoles per liter): $\mathrm{NaCl}, 136 ; \mathrm{KCl}, 5.4$; $\mathrm{KH}_{2} \mathrm{PO}_{4}, 0.44 ; \mathrm{Na}_{2} \mathrm{HPO}_{4}, 0.34 ; \mathrm{CaCl}_{2}$, 1; D-glucose, 5.6; $N$-2-hydroxyethylpiperazine- $N$ '-2-ethanesulfonic acid, 10; $\mathrm{pH}$ 7.4. Cells were counted using a cell counter (CASY 1 Model TT; Schärfe System GmbH, Reutlingen, Germany). Cells were centrifuged at $400 \mathrm{~g}$ for 5 minutes and resuspended in RPMI-1640 (Sigma-Aldrich Chemie $\mathrm{GmbH}$ ) with 10\% FCS (Invitrogen GmbH, Karlsruhe, Germany) and $25 \mathrm{mmol} / \mathrm{l}$ HEPES. Cells were given in $60-\mathrm{mm}^{2}$ tissue flasks with a total of $1.8 \times 10^{7}$ cells. Cells were incubated for 2 hours in a humidified incubator at $37^{\circ} \mathrm{C}$ and $5 \% \mathrm{CO}_{2}$. Cells were then stimulated for 6 hours in an humidified incubator at $37^{\circ} \mathrm{C}$ and $5 \% \mathrm{CO}_{2}$ with $100 \mathrm{U} / \mathrm{ml} \mathrm{IFN- \gamma}$ (Sigma-Aldrich Chemie GmbH) and $1 \mu \mathrm{g} / \mathrm{ml}$ LPS (LPS serotype 0111:B4 from Escherichia coli; Sigma-Aldrich Chemie GmbH). Incubation of cells was done in the absence or presence of PAA in various concentrations $(0.1-2 \mathrm{mmol} / \mathrm{l})$ in the presence of plasma from patients with end-stage renal failure $(n=6)$ on regular hemodialysis and healthy control subjects $(n=6)$, or in the presence of phenylalanine $(1 \mathrm{mmol} / \mathrm{l})$, homogentisic acid $(1 \mathrm{mmol} / \mathrm{l})$, and phenylethylamine (1 $\mathrm{mmol} / \mathrm{l})$. After incubation, cells were harvested and centrifuged (400 $g$ for 5 minutes). The pellet was immediately frozen in liquid nitrogen and stored at $-80^{\circ} \mathrm{C}$ for further analysis.

Preparation and stimulation of RAW 264.7 cells. The murine macrophage cell line of RAW 264.7 was obtained from the European Collection of Animal Cell Cultures (Salisbury, United Kingdom). Cells were cultured in DMEM/F-12 supplemented with $2.44 \mathrm{~g} / 1 \mathrm{NaHCO}_{3}, 2$ $\mathrm{mmol} / \mathrm{l} \mathrm{L}$-glutamine, $1 \mathrm{mmol} / \mathrm{l}$ sodium pyruvate, $10 \%$ FCS, and penicillin/streptomycin $(100 \mathrm{U} / \mathrm{ml}$ and 100 $\mathrm{mg} / \mathrm{ml}$, respectively). Cultures were maintained in a humidified incubator in $5 \% \mathrm{CO}_{2}$ at $37^{\circ} \mathrm{C}$. Cells were plated at a concentration of $10^{5} \mathrm{cells} / \mathrm{ml}$ and used for the experiment when they reached $80 \%$ confluence. Cells were then stimulated for 6 hours or 12 hours in an humidified incubator at $37^{\circ} \mathrm{C}$ and $5 \% \mathrm{CO}_{2}$ with $1 \mu \mathrm{g} / \mathrm{ml}$ LPS (serotype 0111:B4 from E. coli; Sigma-Aldrich Chemie $\mathrm{GmbH}$ ). Incubation and further processing of the cells were done as described above for mononuclear leukocytes. In the experiments, cells were serum starved by incubation in a serum-reduced medium (DMEM/ F-12) supplemented with $2.44 \mathrm{~g} / 1 \mathrm{NaHCO}_{3}, 2 \mathrm{mmol} / \mathrm{l}$ 
L-glutamine, $1 \mathrm{mmol} / 1$ sodium pyruvate, $1.0 \% \mathrm{FCS}$, and penicillin/streptomycin $(100 \mathrm{U} / \mathrm{ml}$ and $100 \mathrm{mg} / \mathrm{ml}$, respectively) for 24 hours before use.

Preparation and stimulation of endothelial cells. To test the influence of PAA on eNOS, ECV304 cells were used. ECV304 is a spontaneously transformed, immortal endothelial cell line established from the vein of an apparently normal human umbilical cord. Cells were provided by the European Collection of Animal Cell Cultures. Cells were grown in medium M199 supplemented with $10 \%$ FCS, $100 \mathrm{U} / \mathrm{ml}$ penicillin, and 100 $\mu \mathrm{g} / \mathrm{ml}$ streptomycin. Cells were maintained in an standard culture incubator with humidified air containing $5 \% \mathrm{CO}_{2}$ at $37^{\circ} \mathrm{C}$. In the experiments, cells were serumstarved by incubation in a serum-free medium M199 containing antibiotics for 48 hours before use.

Preparation of RNA and real-time PCR. Primers and probes for murine and human iNOS and for the housekeeping gene $\beta$-actin were designed using the computer program Primer Express 2.0 (Perkin Elmer Applied Biosystems, Foster City, California, USA) (Table 2). Except for $\beta$-actin, primers were located in two different exons.

Total RNA from RAW 264.7 cells or mononuclear leukocytes was extracted using QIAGEN RNeasy MiniKit according to the manufacturer's protocol (Qiagen GmbH, Hilden, Germany). Target RNA (1-2 $\mu \mathrm{g})$ was reverse transcribed using $100 \mathrm{U}$ Superscript II RT (Invitrogen $\mathrm{GmbH}$ ) at $42^{\circ} \mathrm{C}$ for 80 minutes in the presence of $50 \mathrm{mmol} / \mathrm{l} \mathrm{Tris-} \mathrm{HCl}(\mathrm{pH} 8.3), 5.7 \mathrm{mmol} / \mathrm{l} \mathrm{KCl}$, $3 \mathrm{mmol} / 1 \mathrm{MgCl}_{2}, 5 \mathrm{mmol} / \mathrm{l}$ DTT, $0.5 \mathrm{mmol}$ dNTPs, $8 \mathrm{U}$ RNasin (Promega Corp., Madison, Wisconsin, USA), and $5 \mu \mathrm{mol} / 1$ oligo(dT) ${ }_{16}$ (Perkin-Elmer Applied Biosystems). For every reaction set, one RNA sample was performed without Superscript II RT to provide a negative control in subsequent $\mathrm{PCR}$ reaction.

Real-time PCR was done by using the ABI prism 7700 sequence detector (TaqMan; Perkin Elmer Applied Biosystems). The method and the quantification procedure is extensively described elsewhere (27). Commercial reagents (TaqMan PCR Reagent Kit, Perkin Elmer Applied Biosystems) and conditions according to the manufacturer's protocol were applied $(2.5 \mu \mathrm{l}$ of cDNA and oligonucleotides at a final concentration of $200 \mathrm{nmol} / \mathrm{l})$. Each reaction also contained $100 \mathrm{nmol} / \mathrm{l}$ of the corresponding detection probe (Table 2).

Each PCR amplification was performed in triplicate wells, using the following conditions: 2 minutes at $50^{\circ} \mathrm{C}$ and 10 minutes at $94^{\circ} \mathrm{C}$, followed by a total of 40 or 45 two-temperature cycles $\left(15\right.$ seconds at $94^{\circ} \mathrm{C}$ and 1 minute at $60^{\circ} \mathrm{C}$ ).

Preparation of proteins from RAW 264.7 cells, PAGE, and Western blot analysis. Harvested RAW 264.7 cells after stimulation were lysed in lysis buffer containing 50 $\mathrm{mmol} / \mathrm{l} \mathrm{Tris-Cl}$ (pH 7.4), $150 \mathrm{mmol} / \mathrm{l} \mathrm{NaCl}, 100 \mu \mathrm{g} / \mathrm{ml}$ PMSF, $1 \%$ Nonident P-40, and $4 \%$ protease inhibitor cocktails. Protein concentrations in the cell lysates were stored at $-70^{\circ} \mathrm{C}$ until further measurement.

Aliquots were subjected to SDS-PAGE on $7.5 \%$ polyacrylamide slab gels and blotted onto PVDV membranes. PVDV blots were blocked for 1 hour in Tris-buffered saline (TBS; $150 \mathrm{mmol} / \mathrm{l} \mathrm{NaCl}, 20 \mathrm{mmol} / \mathrm{l}$ Tris, pH 7.5) containing 5\% nonfat milk and incubated overnight at $4^{\circ} \mathrm{C}$ with $\mathrm{Ab}$ against iNOS (1:10,000 dilution; Santa Cruz Biotechnology Inc., Heidelberg, Germany) in TBS containing 5\% nonfat milk. Membranes were washed in TBS and incubated with goat anti-rabbit alkaline phosphatase-conjugated $\mathrm{Ab}$ (1:3,000 dilution) for 1.5 hours. After further washing with TBS, blots were detected by the enhanced chemiluminescence method using an immunoblot assay kit (Bio-Rad Laboratories $\mathrm{GmbH}$, Munich, Germany).

Measurement of NO production. NO production was assayed by measuring the accumulation of nitrite in the culture medium by the Griess reaction, using sodium nitrite as a standard. Aliquots of culture medium were mixed with an equal volume of Griess reagent [ $1 \%$ sulphanilamide $/ 0.1 \% N$-(1-napthyl) ethylenediamine dihydrochloride in $5 \%$ phosphoric acid], the mixture incubated at room temperature for 10 minutes, and the absorbance at $540 \mathrm{~nm}$ measured using a photometer (iEMS reader; Labsystems, Helsinki, Finland). Standard curves were constructed using known concentrations of sodium nitrite. Net NO production after stimulation with LPS was calculated by subtracting basal NO production from total production and expressed as the percentage release of NO relative to control. NO production in ECV304 cells was measured after stimulation with acetylcholine $(1 \mu \mathrm{mol} / \mathrm{l})$.

Cell viability. The cell viability was assessed using Trypan blue dye. Trypan blue dye solution (0.4\%) was added to the cell suspension at a ratio of 1:2. After mixing, the

\section{Table 2}

Primer and probe sequences for murine and human iNOS and for $\beta$-actin (146 bp)

Name $\quad$ Sequence $\left(5^{\prime}-3^{\prime}\right) \quad \begin{gathered}\text { Amplicon } \\ \text { length (bp) }\end{gathered}$

Murine iNOS

miNOS-TP CGG GCA GCC TGT GAG ACC TTT GA

95

miNOS-RP

CAT TGG AAG TGA AGC GTT TCG

miNOS-FP CAG CTG GGC TGT ACA AAC CTT

Murine $\beta$-actin

MPact-TP

CAC TGC CGC ATC СТС ТTC СТС СC

148

Mßact-RP

CAA TAG TGA TGA CCT GGC CGT

Mßact-FP

AGA GGG AAA TCG TGC GTG AC

Human iNOS

hiNOS-TP

hiNOS-RP

hiNOS-FP

TCC GAC ATC CAG CCG TGC CA

CAG GAG AGT TCC ACC AGG ATG

66

TCA AAT CTC GGC AGA ATC TAC AAA

Human $\beta$-actin

hßact-TP TCA AGT ATC ATT GCT CCT CCT GAG CGC 146

$h \beta$ act-RP

GCC GAT CCA CAC GGA GTA CT

hßact-FP

CTG GCA CCC AGC ACA ATG

6-carboxyfluorescein labeled at the $5^{\prime}$ end and 6-carboxytetramethylrhodamine labeled at the $3^{\prime}$ end. All cDNA sequences were obtained from the Genbank database. TP, fluorogenic probe; RP, reverse primer; FP, forward primer. 
cells were observed under a microscope. Cells not stained with the dye were regarded as living, and cell viability was expressed as the percentage of living to total cells.

NMR spectroscopy. To quantitate PAA concentrations, proton-NMR $\left({ }^{1} \mathrm{H}-\mathrm{NMR}\right)$ measurements were carried out using a Bruker AMX 400 FT spectrometer (Bruker Analytische Messtechnik GmbH, Rheinstetten, Germany) operating at a field strength of $400 \mathrm{MHz} . \mathrm{D}_{2} \mathrm{O}(50 \mu \mathrm{l})$, and $50 \mu \mathrm{l}$ of a solution of $0.75 \% 3$-trimethylsilyl-[2,2,3,3,$\left.{ }^{2} \mathrm{H}_{4}\right]$-propionate in $\mathrm{D}_{2} \mathrm{O}$ was added to samples $(500 \mu \mathrm{l})$ and mixed thoroughly by vortex for 3 minutes at room temperature. The sample was poured into a glass NMR test tube with an inner diameter of $5 \mathrm{~mm}$. All spectra were recorded at a controlled probe temperature of $25^{\circ} \mathrm{C}$. The signal from deuterium oxide was used to optimize the homogeneity of the magnetic field, and the fine adjustment was done by inspection of the free-induction decay obtained without water suppression. A field frequency was provided by detecting the deuterium signal of deuterium oxide. The proton spectra were obtained by using a flip angle of 90 degrees ( 6.2 microseconds). Pulse conditions were 128 accumulations collected into $32-\mathrm{K}$ computer points using 90-degree pulses and a relaxation delay of 6 seconds. The spectral width was $5 \mathrm{kHz}$. Using these conditions, spectra were fully $\mathrm{T}_{1}$ relaxed, and, for sharp resonances, $T_{2}$ relaxation during the period $3 t$ was not observed (28). The water resonance at 4.8 parts per million ( $\mathrm{ppm}$ ) was suppressed by presaturation during relaxation and mixing time with a 90-degree sequence $\left(\mathrm{d}_{1}-90^{\circ}-\mathrm{d}_{0}-90^{\circ}-\mathrm{d}_{9}-90^{\circ}\right.$-free induction decay) (29). The spinning rate was 20 rotations per second. The accumulation time was 10.4 minutes. Shifts were referenced to 3-trimethylsilyl-[2,2,3,3,- $\left.{ }^{2} \mathrm{H}_{4}\right]$-propionate (TSP) at $0 \mathrm{ppm}$. The relative intensities of the resonance of PAA were determined by comparison with the intensity of the resonance of TSP. Resonance intensity can be used to determine concentration provided that the line widths are comparable. Peak height can be used to determine concentrations provided that the line widths are comparable (30). Using the internal reference, concentrations were calculated from the peak heights of identified substance. Calibration curves with identified substances revealed a linear relationship between concentration and peak height. Therefore, the resonance intensity of the respective substance was used for quantification (30). To quantify protein binding of PAA, native plasma samples were divided into two portions, one of which underwent NMR spectroscopy immediately, and the other was deproteinized with $0.6 \mathrm{~mol} / \mathrm{l}$ perchloric acid, centrifuged at $2,100 \mathrm{~g}$ and $4^{\circ} \mathrm{C}$ for 5 minutes. The supernatant was neutralized by $\mathrm{KOH}$. After deproteination, this sample was analyzed by NMR spectroscopy, too.

Statistics. All data are presented as mean plus or minus SEM. Statistical analyses were done with GraphPad Prism version 3.0 (GraphPad Software for Science Inc., San Diego, California, USA). Comparisons between the groups were made using the nonparametric Wilcoxon rank sum test and nonparametric Wilcoxon matched pairs test, as appropriate. A two-tailed $P$ value of less than 0.05 was considered significant.

\section{Results}

As shown in Figure 1a, the stimulation of mononuclear leukocytes from healthy subjects with $1 \mu \mathrm{g} / \mathrm{ml}$ LPS and

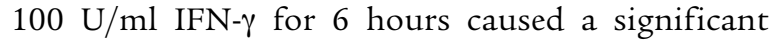
increase in iNOS expression. In the presence of plasma from patients with end-stage renal failure on regular hemodialysis the LPS- and IFN- $\gamma$-induced iNOS mRNA expression was dose dependently blocked, whereas plasma from healthy persons did not reduce LPS- and IFN- $\gamma$-induced iNOS-expression.

For the fractionation of the hemofiltrate from patients with end-stage renal failure a preparative reversed-phase column was used. Because of the great
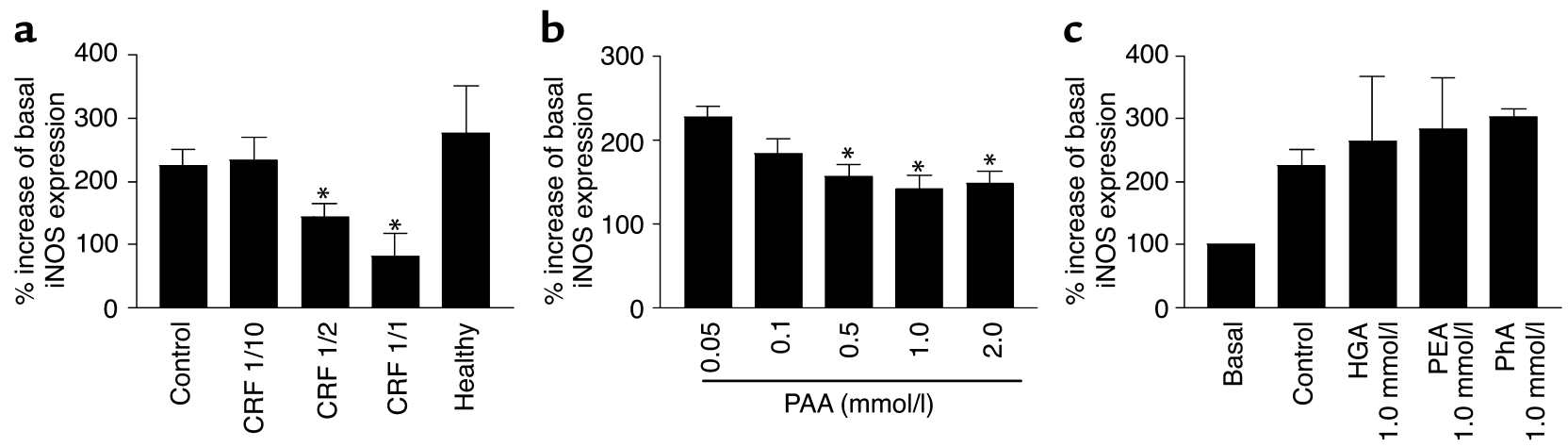

\section{Figure 1}

Plasma from patients with end-stage renal failure and healthy control subjects show effects of PAA and some of its derivatives on iNOS mRNA expression measured by real-time PCR without (basal; set to 100\%) and after stimulation by LPS ( $1 \mu \mathrm{g} / \mathrm{ml})$ and IFN- $\gamma(100 \mathrm{U} / \mathrm{ml})(\mathrm{control})$ in mononuclear leukocytes. (a) Expression of iNOS in the presence of various amounts of plasma diluted in PBS from patients with CRF on regular hemodialysis (end-stage renal failure) in the presence of plasmas from healthy persons (healthy). The plasma was diluted with physiologic salt solution $1 / 10,1 / 2$, and 1/1, respectively. Basal unstimulated iNOS expression was set to $100 \%$; each $n=6$. (b) Expression iNOS in the presence of various concentrations of PAA $(0.05 \mathrm{mmol} / \mathrm{l}, 0.1 \mathrm{mmol} / \mathrm{l}, 0.5 \mathrm{mmol} / \mathrm{l}, 1.0 \mathrm{mmol} / \mathrm{l}$, and $2.0 \mathrm{mmol} / \mathrm{l})$. Control value as in a. Basal unstimulated iNOS expression was set to $100 \%$. (c) Expression of iNOS in the presence of homogentisic acid (HGA; $1.0 \mathrm{mmol} / \mathrm{I})$, phenylethyl amine (PEA; $1.0 \mathrm{mmol} / \mathrm{l})$, or phenylalanine $(\mathrm{PhA} ; 1.0 \mathrm{mmol} / \mathrm{l})(n=6) .{ }^{*} P<0.05$ compared with control. 


\section{Table 3}

Data of the mass spectrum of the gas chromatography/mass spectrometry analysis of PAA showing an inhibitory effect on iNOS expression

$\begin{array}{lc}\text { Fragment mass } & \begin{array}{c}\text { Relative intensity } \\ \text { (Da) }\end{array} \\ 45 & 8.2 \\ 47 & 6.0 \\ 65 & 10.0 \\ 73 & 100.0 \\ 74 & 12.0 \\ 75 & 46.8 \\ 76 & 3.4 \\ 77 & 4.6 \\ 89 & 5.0 \\ 90 & 6.2 \\ 91 & 15.0 \\ 117 & 2.6 \\ 118 & 1.2 \\ 121 & 1.0 \\ 137 & 6.0 \\ 164 & 18.0 \\ 165 & 8.0 \\ 193 & 16.0 \\ 194 & 3.0 \\ 195 & 2.0 \\ \end{array}$

The fragment masses are identical to those found in the NIST Mass Spectral Database.

amount of hemofiltrate substances, chromatography was performed in the displacement mode. Moreover, for this separation step an anionic ion-pair reagent was used. By using this procedure the large amount of hemofiltrate was separated by one chromatographic step. The LPS-induced expression of iNOS mRNA in mononuclear leukocytes was decreased in the presence of one fraction of the displacement chromatography eluting at 630.3 minutes.

This fraction was next separated by reversed-phase chromatography with $0.1 \%$ TFA in water as an anionic ion-pair reagent. For this separation step an analytical reversed-phase column was used in the gradient mode. The analytical reversed-phase column in the gradient mode allows effective separation of the hemofiltrate substances while being applicable at this stage without overloading the column, since the bulk of interfering substances was removed in the preceding steps.

One fraction decreasing the LPS plus IFN- $\gamma$-induced iNOS expression was determined at a retention time of 55.9 minutes. Next, reversed-phase chromatography of this fraction was performed with $40 \mathrm{mmol} / \mathrm{l}$ TEAA in water as a cationic ion-pair reagent. For this fraction step another analytic reversed-phase column with alternative reversed-phase gel was used in the gradient modus. For further variation of the separation conditions, instead of using TFA as ion-pair reagent TEAA was used.

The fraction with an decreasing effect on the iNOS expression was next separated by the identical reversedphase gel, but in presence of TFA as an anionic ion-pair reagent. The separation of the fraction eluting at 33.1 minutes by reversed-phase chromatography with $0.1 \%$ TFA in water and acetonitrile as eluent revealed one obviously homogeneous fraction decreasing iNOS expression and eluting at 44.6 minutes.

The underlying substance of this chromatographic fraction had a blocking effect on the LPS plus IFN- $\gamma-$ induced expression of iNOS mRNA in mononuclear leukocytes. This substance was analyzed by mass spectrometry. The mass spectrometry data are given in Table 3. By interpretation of the mass spectrum, and also by comparison with the NIST mass spectral database, the underlying substance was identified as PAA. The mass spectrum of PAA was clearly distinct from those of other derivatives of phenylalanine, such as homogentisic acid, phenylethylamine, and phenylalanine.

After PAA had been isolated and identified as an endogenous iNOS inhibitor, the effects of authentic PAA were assessed in detail. First, the effects of PAA on iNOS mRNA expression were examined. Authentic PAA inhibited LPS-induced plus IFN- $\gamma$-iNOS expression in a dose-dependent manner (Figure 1b).

To test whether this PAA effect was specific for PAA and did not reflect unspecific toxicity, several phenylalanine derivatives were tested for their effects on iNOS expression. In the presence of phenylalanine (1 $\mathrm{mmol} / \mathrm{l})$, homogentisic acid $(1 \mathrm{mmol} / \mathrm{l})$, and phenylethylamine $(1 \mathrm{mmol} / \mathrm{l})$ the LPS- and IFN- $\gamma$-induced iNOS expression was not significantly affected (Figure 1c). Moreover, viability of RAW 264.7 cells was not affected by PAA (Figure 2).

From the above findings the question arose whether PAA itself was the effective agent or if metabolites of PAA affected iNOS mRNA expression. The NMR spectra obtained from PAA after incubation for 0 and 60 minutes with mononuclear leukocytes were essentially unchanged. The PAA signal at 60 minutes was $98 \% \pm 6 \%$ of the 0 -minute signal, indicating that PAA was not

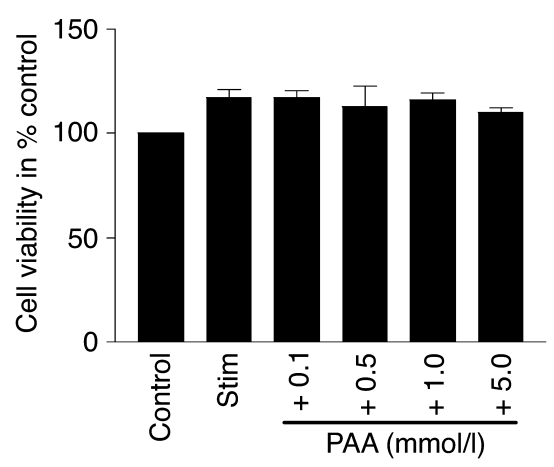

Figure 2

Cell viability of RAW 264.7 cells in the presence of PAA. Cell viability was assessed using Trypan blue dye. RAW 264.7 cells were stimulated (stim) or not (control) for 12 hours with LPS $(1 \mu \mathrm{g} / \mathrm{ml})$. Viability of cells was measured after stimulation with LPS and in the presence of various concentrations of PAA $(0.1 \mathrm{mmol} / \mathrm{l}, 0.5 \mathrm{mmol} / \mathrm{l}$, $1.0 \mathrm{mmol} / \mathrm{l}$, and $5.0 \mathrm{mmol} / \mathrm{l})$. Data are mean $\pm \operatorname{SEM}(n=6) . P<0.05$ compared with stimulated cells. 


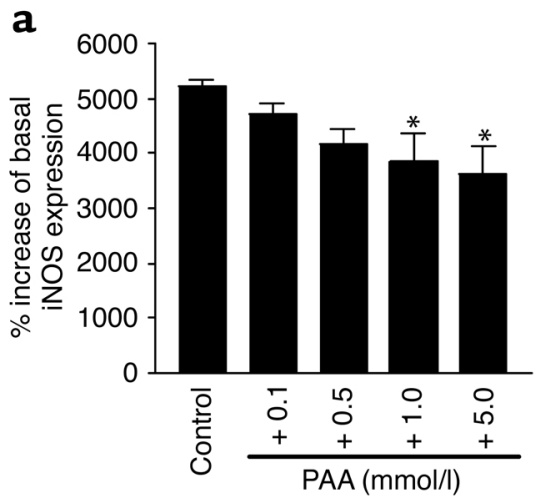

b

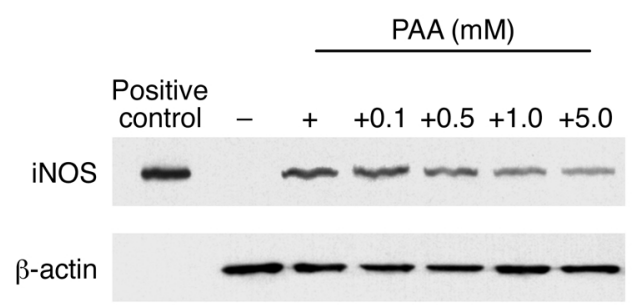

c

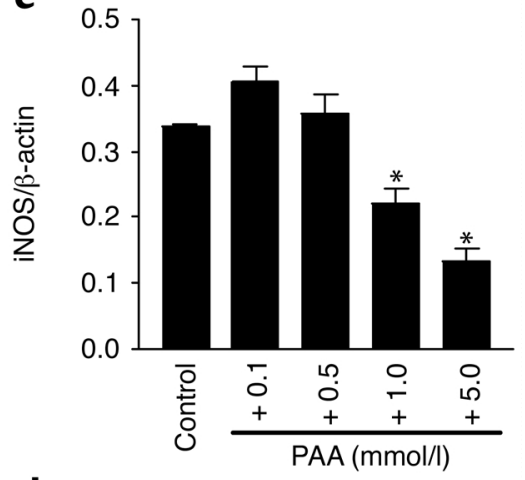

d

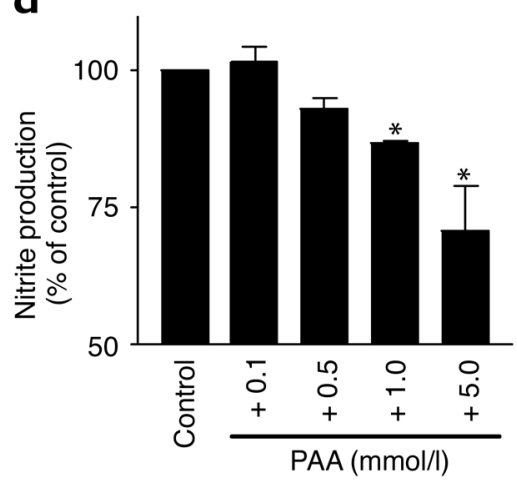

Figure 3

Expression of iNOS measured by real-time PCR, protein blotting of iNOS, or nitrite formation in RAW 264.7 cells. (a) The iNOS expression was measured by real-time PCR after stimulation by LPS $(1 \mu \mathrm{g} / \mathrm{ml})$ (control) and in the presence of various concentrations of PAA $(0.1 \mathrm{mmol} / \mathrm{l}$, $0.5 \mathrm{mmol} / \mathrm{l}, 1.0 \mathrm{mmol} / \mathrm{I}$, and $5.0 \mathrm{mmol} / \mathrm{l})$. Basal, unstimulated iNOS expression was set to $100 \%(n=6) .{ }^{*} P<0.05$ compared with control. (b) Representative protein blotting of iNOS and $\beta$-actin after 12 hours of stimulation (+) or without stimulation (-) of RAW 264.7 cells with LPS $(1 \mu \mathrm{g} / \mathrm{ml})$ and in the presence of PAA $(0.1 \mathrm{mmol} / \mathrm{l}, 0.5 \mathrm{mmol} / \mathrm{l}, 1.0 \mathrm{mmol} / \mathrm{l}$, and 5.0 $\mathrm{mmol} / \mathrm{I})$. The iNOS protein was detected as a band with a molecular mass of approximately $125 \mathrm{kDa}$. (c) Signals of iNOS were quantified and normalized to those of $\beta$-actin using a bioimaging analyzer. Data represent means of triplicate determinations from each of three protein preparations $(n=3)$. ${ }^{*} P<0.05$ compared with control. (d) Effect of various concentrations of PAA $(0.1 \mathrm{mmol} / \mathrm{I}, 0.5 \mathrm{mmol} / \mathrm{l}, 1.0 \mathrm{mmol} / \mathrm{l}$, and $5.0 \mathrm{mmol} / \mathrm{I})$ on LPS-induced nitrite production in RAW 264.7 cells. Data are means $\pm \operatorname{SEM}(n=6) .{ }^{*} P<0.05$ compared with control $(+)$.

metabolized during this time period in significant amounts. Furthermore, the PAA effects on iNOS mRNA expression were also tested in RAW 264.7 cells. Real-time PCR revealed a significant expression of iNOS mRNA in these cells after 6 hours of stimulation with $1 \mu \mathrm{g} / \mathrm{ml}$ LPS. Furthermore, in these cells PAA showed a concentrationdependent effect on iNOS mRNA expression similar to that in mononuclear leukocytes (Figure 3a).

To confirm the functional relevance of PAA effects on iNOS mRNA expression, iNOS protein as well as LPSinduced nitrite production were determined in RAW 264.7 cells. In the presence of PAA in concentrations greater than $1 \mathrm{mmol} / \mathrm{l}$, the amount of iNOS protein was significantly $(P<0.05)$ reduced (Figure 3 , b and c). Likewise, nitrite production by iNOS induced by $1 \mu \mathrm{g} / \mathrm{ml}$ LPS was significantly reduced by PAA (Figure $3 \mathrm{~d}$ ). On the other hand, the acetylcholine-induced nitrite production by eNOS of endothelial ECV304 cells was not significantly affected by the administration of PAA (Figure 4).
In plasma of healthy subjects $(n=39)$ PAA was not detectable. Experiments with authentic PAA revealed a detection limit by NMR analysis in the range of 5-10 $\mu \mathrm{mol} / \mathrm{l}$. On the other hand, in patients with end-stage renal failure, plasma concentrations of PAA were $3.49 \pm 0.33 \mathrm{mmol} / \mathrm{l}$ $(n=41 ; P<0.01$ versus control). These concentrations were obtained in plasma from patients with end-stage renal failure before a regular hemodialysis session. The plasma PAA concentrations of the patients with endstage renal failure used for the experiments of Figure 1a were $2.5 \pm 0.5 \mathrm{mmol} / \mathrm{l}(n=6)$. Next, we quantified the portion of protein-bound PAA in blood plasma from patients with end-stage renal failure. After deproteinization, $69.8 \% \pm 22.5 \%$ of PAA detected in untreated samples was found $(n=8)$. Accordingly, in unprocessed ultrafiltrate from patients with end-stage renal failure, $52.7 \% \pm 12.6 \%$ of the plasma PAA concentration was measured by $\operatorname{NMR}(n=10)$.

\section{Discussion}

Several reports indicate that in CRF NO production is reduced $(31,32)$. Given the important function of $\mathrm{NO}$ in maintaining vascular function and integrity, deficient NO production may be one key step leading to the functional and structural vascular changes in renal failure. The present study focused on the PAA effects on iNOS expression, since it is known that increased iNOS expression is a compensatory mechanism when endothelial NO production is inadequate (33).

The present study may offer one explanation of the decreased NO bioavailability in patients with renal failure. Plasma from patients with CRF inhibited the expression of iNOS, whereas plasma from healthy subjects had no effect. The eNOS activity was unaffected by PAA. Using hemofiltrate, we isolated and identified the iNOS inhibitor in patients with end-stage renal failure to be PAA. PAA is a degradation product of the amino acid phenylalanine. Phenylalanine is primarily metabolized by phenylalanine hydroxylase to tyrosine. In addition, phenylalanine is decarboxylated to phenylethylamine, $90 \%$ of which is oxidized to PAA and the 


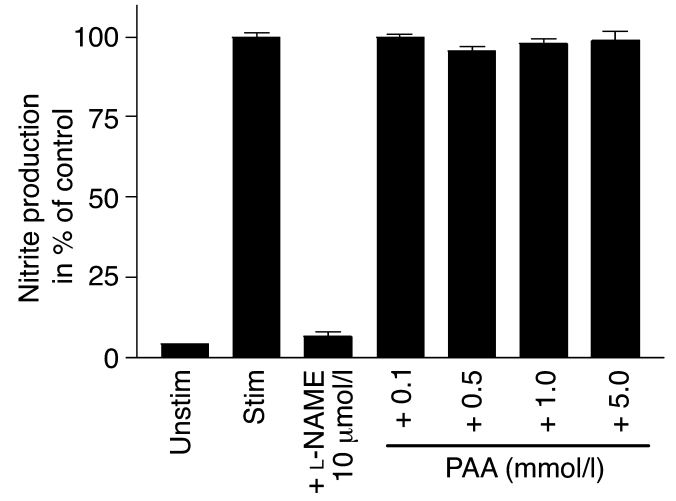

Figure 4

Nitrite formation in ECV304 cells. Nitrite accumulation was measured after 30 minutes with (stim) or without (unstim) stimulation of ECV304 with acetylcholine $(1 \mu \mathrm{mol} / \mathrm{l})$. ECV304 cells were stimulated with acetylcholine in the absence (stim) or presence of PAA $(0.1$ $\mathrm{mmol} / \mathrm{I}, 0.5 \mathrm{mmol} / \mathrm{I}, 1.0 \mathrm{mmol} / \mathrm{l}$, and $5.0 \mathrm{mmol} / \mathrm{l})$ and L-NAME (10 $\mu \mathrm{mol} / \mathrm{I})$. Data are mean $\pm \operatorname{SEM}(n=6) .{ }^{*} P<0.05$ compared with stimulation. L-NAME, $N^{\mathrm{G}}$-nitro-L-arginine methyl ester.

remainder to mandelic acid (34). Using NMR, we measured plasma concentrations of PAA in patients with end-stage renal failure and healthy control subjects. As suggested by the findings obtained with hemofiltrate, plasma PAA concentrations in patients with renal failure far exceeded those in healthy in controls.

The principal finding of the present study, that PAA accumulates in patients with end-stage renal failure, inhibits iNOS expression, and, consequently, NO production, may help our understanding of the vascular and hemodynamic changes in end-stage renal failure for several reasons.

Firstly, reduced iNOS expression may contribute to accelerated atherosclerosis $(13,35)$ and hence to increased cardiovascular morbidity in these patients. NO metabolism has been implicated in the pathogenesis of arteriosclerosis (36). NO helps to maintain the integrity of the vascular endothelium by inhibiting the expression of adhesion molecules. NO inhibits ADP-induced human platelet aggregation, mediated by a cGMPdependent mechanism (37). Moreover, NO attenuates leukocyte adhesion and chemotaxis, important steps in atherogenesis. An enhanced leukocyte adhesion to endothelium has been observed during infusion of NOS inhibitors in cats. This effect was reversed by infusion of L-arginine and an $\mathrm{Ab}$ to the adhesion complex CD11b/CD18 on the leukocyte (38). The monocyte chemotaxis is inhibited by NO via a cGMP-dependent pathway (39). These observations, along with others, strongly suggest that NO blocks inflammatory cell adhesion and migration into the subintimal space, thereby limiting the deleterious effects of the inflammatory cascade and the subsequent development of arteriosclerosis. Secondly, there is increasing evidence that decreased renal NO production plays a key role in causing and/or mediating the complex changes of renal hemodynamics associated with the progression of CRF $(16,40)$. It has been proposed that NO production by iNOS in medullary thick ascending limbs serves to maintain and regulate medullary blood flow and oxygenation (41). There is also evidence that NO induces natriuresis by antagonizing the effect of Ang II on sodium reabsorption in proximal tubuli (41) and by directly inhibiting renal tubular $\mathrm{Na}^{+} / \mathrm{K}^{+}$ATPase (42).

On the other hand, the role of iNOS in modulating the development of atherosclerosis is less clear than should be expected from those beneficial effects of NO on vasculature. NO has both antioxidant and oxidant effects. The latter depend mainly on further reactions of $\mathrm{NO}$ with reactive oxygen species, producing a variety of reactive nitrogen species, which are powerful oxidants: $\mathrm{NO}$ and $\mathrm{O}_{2}{ }^{-}$form peroxynitrite $\left(\mathrm{ONOO}^{-}\right)$, and myeloperoxidase can produce $\mathrm{NO}_{\mathrm{x}}$ from $\mathrm{NO}^{2-}$, which is a reaction product of $\mathrm{NO}$ and $\mathrm{H}_{2} \mathrm{O}_{2}(43)$. Both $\mathrm{NO}_{x}$ and $\mathrm{ONOO}^{-}$ are known to induce protein nitration, an important mechanism of oxidative injury $(44,45)$. Possibly as a consequence of reduced iNOS-induced oxidative stress, in apoE/iNOS double-knockout mice, a combined genetic model of iNOS deficiency and atherosclerosis, iNOS deficiency was protective against atherosclerosis (46).

Increased NO production may thus divergently affect the progression of atherosclerosis. Moreover, the present findings may have implications for iNOS expression in at least two cell types: (a) iNOS is expressed in both VSMCs and mononuclear leukocytes. The effects of PAA on iNOS expression in mononuclear leukocytes may therefore be extrapolated to iNOS expression in VSMCs. Indeed, in several experimental models iNOS expression in mononuclear cells and VSMCs was found to be inducible by the same experimental procedures (47-52). (b) Macrophages and mononuclear leukocytes are known to play important roles in the development of atherosclerosis (53).

In this context, increased iNOS expression has consistently been observed (54) and, as detailed above, may be of pathogenetic relevance. Therefore, beyond the extrapolation of the leukocyte findings to VSMCs, the present data may also be relevant to iNOS expression in mononuclear cells infiltrating the vessel wall.

The experiments demonstrating an inhibitory effect of PAA on iNOS expression may be relevant to the clinical setting of end-stage renal failure: plasma PAA levels in end-stage renal failure patients as determined by NMR are similar to those completely inhibiting iNOS expression in isolated mononuclear leukocytes. This also remains true when the percentage of protein-bound PAA is considered. Both in ultrafiltrate and in supernatant obtained after deproteinization, about $60 \%$ of total PAA was recovered, with the percentage of free PAA found in perchloric acid-treated samples being slightly higher, probably resulting from additional PAA release from precipitated proteins. The mechanism whereby PAA inhibits iNOS expression is still open. Apparently, PAA is taken up by mononuclear leukocytes in sufficient amounts to be effective intracellularly. 
In conclusion, we demonstrated that PAA is a potent inhibitor of iNOS expression accumulating in patients with end-stage renal failure. This mechanism may contribute to increased atherosclerosis and cardiovascular morbidity in CRF patients.

\section{Acknowledgments}

We thank the Forschungsinstitut für Molekulare Pharmakologie (group of H. Oschkinat), Berlin, Germany, for acquisition of NMR data.

1. Moncada, S., and Higgs, E.A. 1995. Molecular mechanisms and therapeutic strategies related to nitric oxide. FASEB J. 9:1319-1330.

2. Katsuyama, K., Shichiri, M., Marumo, F., and Hirata, Y. 1998. NO inhibits cytokine-induced iNOS expression and NF-kappaB activation by interfering with phosphorylation and degradation of IkappaB-alpha. Arterioscler. Thromb. Vasc. Biol. 18:1796-1802.

3. Cornwell, T.L., Arnold, E., Boerth, N.J., and Lincoln, T.M. 1994. Inhibition of smooth muscle cell growth by nitric oxide and activation of cAMPdependent protein kinase by cGMP. Am. J. Physiol. 267:C1405-C1413.

4. De Caterina, R., et al. 1995. Nitric oxide decreases cytokine-induced endothelial activation. Nitric oxide selectively reduces endothelial expression of adhesion molecules and proinflammatory cytokines. J. Clin. Invest. 96:60-68.

5. Gewaltig, M.T., and Kojda, G. 2002. Vasoprotection by nitric oxide: mechanisms and therapeutic potential. Cardiovasc. Res. 55:250-260.

6. Andrew, P.J., and Mayer, B. 1999. Enzymatic function of nitric oxide synthases. Cardiovasc. Res. 43:521-531.

7. Beasley, D., Schwartz, J.H., and Brenner, B.M. 1991. Interleukin 1 induces prolonged L-arginine-dependent cyclic guanosine monophosphate and nitrite production in rat vascular smooth muscle cells. J. Clin. Invest. 87:602-608.

8. Wilcox, J.N., et al. 1997. Expression of multiple isoforms of nitric oxide synthase in normal and atherosclerotic vessels. Arterioscler. Thromb. Vasc. Biol. 17:2479-2488.

9. Yan, Z.Q., Yokota, T., Zhang, W., and Hansson, G.K. 1996. Expression of inducible nitric oxide synthase inhibits platelet adhesion and restores blood flow in the injured artery. Circ. Res. 79:38-44.

10. Collins, T. 1993. Endothelial nuclear factor-kappa B and the initiation of the atherosclerotic lesion. Lab. Invest. 68:499-508.

11. Fukuo, K., et al. 1996. Nitric oxide induces upregulation of Fas and apoptosis in vascular smooth muscle. Hypertension. 27:823-826.

12. Garg, U.C., and Hassid, A. 1989. Inhibition of rat mesangial cell mitogenesis by nitric oxide-generating vasodilators. Am. J. Physiol. 257:F60-F66.

13. Raine, A.E., et al. 1992. Report on management of renal failure in Europe, XXII, 1991. Nephrol. Dial. Transplant. 7(Suppl):7-35

14. Moeslinger, T., and Spieckermann, P.G. 2001. Urea-induced inducible nitric oxide synthase inhibition and macrophage proliferation. Kidney Int. 78(Suppl.):S2-S8.

15. Gupta, A., and Robinson, K. 1997. Hyperhomocysteinaemia and end stage renal disease. J. Nephrol. 10:77-84.

16. Aiello, S., Noris, M., and Remuzzi, G. 1999. Nitric oxide/L-arginine in uremia. Miner. Electrolyte Metab. 25:384-390.

17. Passauer, J., Bussemaker, E., Range, U., Plug, M., and Gross, P. 2000. Evidence in vivo showing increase of baseline nitric oxide generation and impairment of endothelium-dependent vasodilation in normotensive patients on chronic hemodialysis. J. Am. Soc. Nephrol. 11:1726-1734.

18. Aiello, S., Remuzzi, G., and Noris, M. 1998. Nitric oxide/endothelin balance after nephron reduction. Kidney Int. Suppl. 65:S63-S67.

19. Floege, J., et al. 1992. Glomerular cell proliferation and PDGF expression precede glomerulosclerosis in the remnant kidney model. Kidney Int. 41:297-309.

20. Lee, L.K., Meyer, T.W., Pollock, A.S., and Lovett, D.H. 1995. Endothelial cell injury initiates glomerular sclerosis in the rat remnant kidney.J. Clin. Invest. 96:953-964.

21. Ketteler, M., Border, W.A., and Noble, N.A. 1994. Cytokines and L-arginine in renal injury and repair. Am. J. Physiol. 267:F197-F207.

22. Wheeler, M.A., Smith, S.D., Saito, N., Foster, H.E., Jr., and Weiss, R.M. 1997. Effect of long-term oral L-arginine on the nitric oxide synthase pathway in the urine from patients with interstitial cystitis. J. Urol. 158:2045-2050.

23. Lonnemann, G. 1998. Assessment of the quality of dialysate. Nephrol. Dial. Transplant. 13(Suppl.):17-20.

24. Daugirdas, J.T. 1995. Simplified equations for monitoring Kt/V, PCRn, $\mathrm{eKt} / \mathrm{V}$, and ePCRn. Adv. Ren. Replace. Ther. 2:295-304.

25. Daugirdas, J.T. 1990. Rapid methods of estimating Kt/V: three formulas compared. ASAIO Trans. 36:M362-M364.
26. Tepel, M., et al. 1995. Lymphocytic $\mathrm{Na}(+)-\mathrm{H}+$ exchange increases after an oral glucose challenge. Circ. Res. 77:1024-1029.

27. Overbergh, L., Valckx, D., Waer, M., and Mathieu, C. 1999. Quantification of murine cytokine mRNAs using real time quantitative reverse transcriptase PCR. Cytokine. 11:305-312.

28. Bell, J.D., Brown, J.C.C., and Sadler, P.J. 1987. High resolution proton magnetic resonance studies of human cerebrospinal fluid. Clin. Sci. 72:563-570.

29. Bodenhausen, G., Kogler, H., and Ernst, R.R. 1984. Selection of coherencetransfer pathway in NMR pulse experiments. J. Magn. Res. 58:370-378.

30. Bell, J.D., et al. 1991. Nuclear magnetic resonance studies of blood plasma and urine from subjects with chronic renal failure. Biochim. Biophys. Acta. 1096:101-107.

31. MacAllister, R.J., Whitley, G.S., and Vallance, P. 1994. Effects of guanidino and uremic compounds on nitric oxide pathways. Kidney Int. 45:737-742.

32. Vallance, P., Leone, A., Calver, A., Collier, J., and Moncada, S. 1992. Accumulation of an endogenous inhibitor of nitric oxide synthesis in chronic renal failure. Lancet. 339:572-575.

33. Hecker, M., Cattaruzza, M., and Wagner, A.H. 1999. Regulation of inducible nitric oxide synthase gene expression in vascular smooth muscle cells. Gen. Pharmacol. 32:9-16.

34. Oberdoerster, J., Guizzetti, M., and Costa, L.G. 2000. Effect of phenylalanine and its metabolites on the proliferation and viability of neuronal and astroglial cells: possible relevance in maternal phenylketonuria. J. Pharmacol. Exp. Ther. 295:295-301.

35. London, G.M., and Drueke, T.B. 1997. Atherosclerosis and arteriosclerosis in chronic renal failure. Kidney Int. 51:1678-1695.

36. Nathan, C., and Xie, Q.W. 1994. Nitric oxide synthases: roles, tolls, and controls. Cell. 78:915-918.

37. Mellion, B.T., et al. 1981. Evidence for the inhibitory role of guanosine 3', 5'-monophosphate in ADP-induced human platelet aggregation in the presence of nitric oxide and related vasodilators. Blood. 57:946-955.

38. Kubes, P., Suzuki, M., and Granger, D.N. 1991. Nitric oxide: an endogenous modulator of leukocyte adhesion. Proc. Natl. Acad. Sci. U. S. A. 88:4651-4655.

39. Bath, P.M. 1993. The effect of nitric oxide-donating vasodilators on monocyte chemotaxis and intracellular cGMP concentrations in vitro. Eur. J. Clin. Pharmacol. 45:53-58.

40. Dumont, Y., D’Amours, M., Lebel, M., and Lariviere, R. 2001. Supplementation with a low dose of L-arginine reduces blood pressure and endothelin-1 production in hypertensive uraemic rats. Nephrol. Dial. Transplant. 16:746-754.

41. Ito, S. 1995. Nitric oxide in the kidney. Curr. Opin. Nephrol. Hypertens. 4:23-30.

42. Morrissey, J.J., et al. 1994. Location of an inducible nitric oxide synthase mRNA in the normal kidney. Kidney Int. 45:998-1005.

43. Hazen, S.L., et al. 1999. Formation of nitric oxide-derived oxidants by myeloperoxidase in monocytes: pathways for monocyte-mediated protein nitration and lipid peroxidation in vivo. Circ. Res. 85:950-958.

44. Leeuwenburgh, C., et al. 1997. Reactive nitrogen intermediates promote low density lipoprotein oxidation in human atherosclerotic intima. J. Biol. Chem. 272:1433-1436.

45. Eiserich, J.P., et al. 1998. Formation of nitric oxide-derived inflammatory oxidants by myeloperoxidase in neutrophils. Nature. 391:393-397.

46. Kuhlencordt, P.J., Chen, J., Han, F., Astern, J., and Huang, P.L. 2001. Genetic deficiency of inducible nitric oxide synthase reduces atherosclerosis and lowers plasma lipid peroxides in apolipoprotein E-knockout mice. Circulation. 103:3099-3104.

47. Akyurek, L.M., et al. 1996. Inducible and endothelial nitric oxide synthase expression during development of transplant arteriosclerosis in rat aortic grafts. Am. J. Pathol. 149:1981-1990.

48. Hattori, Y., Matsumura, M., and Kasai, K. 2003. Vascular smooth muscle cell activation by C-reactive protein. Cardiovasc. Res. 58:186-195.

49. Behr-Roussel, D., Rupin, A., Sansilvestri-Morel, P., Fabiani, J.N., and Verbeuren, T.J. 2000. Histochemical evidence for inducible nitric oxide synthase in advanced but non-ruptured human atherosclerotic carotid arteries. Histochem. J. 32:41-51.

50. Russell, M.E., Wallace, A.F., Wyner, L.R., Newell, J.B., and Karnovsky, M.J. 1995. Upregulation and modulation of inducible nitric oxide synthase in rat cardiac allografts with chronic rejection and transplant arteriosclerosis. Circulation. 92:457-464.

51. Hunter, G.C., et al. 1999. The contribution of inducible nitric oxide and cytomegalovirus to the stability of complex carotid plaque. J. Vasc. Surg. 30:36-49.

52. Clark, R.S., et al. 1996. Inducible nitric oxide synthase expression in cerebrovascular smooth muscle and neutrophils after traumatic brain injury in immature rats. Pediatr. Res. 39:784-790.

53. Binder, C.J., et al. 2002. Innate and acquired immunity in atherogenesis. Nat. Med. 8:1218-1226.

54. Li, A.C., and Glass, C.K. 2002. The macrophage foam cell as a target for therapeutic intervention. Nat. Med. 8:1235-1242. 